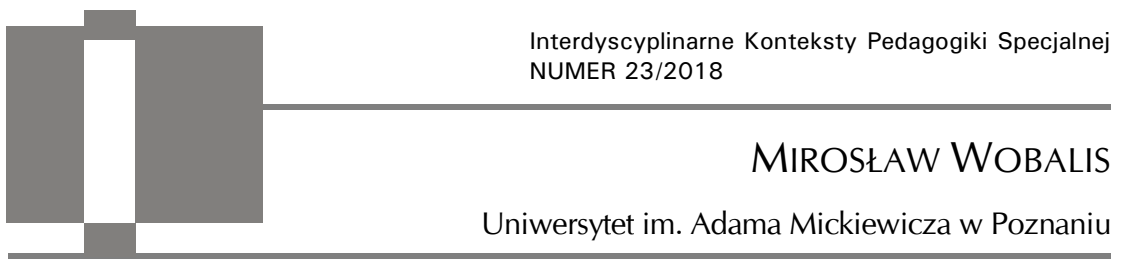

\title{
Cyfrowi komunikatorzy - twórcy czy odtwórcy?
}

\begin{abstract}
Mirosław Wobalis, Cyfrowi komunikatorzy - twórcy czy odtwórcy? [Digital Communicators - creators or imitators?]. Interdyscyplinarne Konteksty Pedagogiki Specjalnej, nr 23, Poznań 2018. Pp. 125-142. Adam Mickiewicz University Press. ISSN 2300-391X. DOI: https://doi.org/10.14746/ikps.2018.23.07
\end{abstract}

The article touches upon the issue of influence of modern digital media on the attitudes of recipients/ broadcasters (digital communicators) related to their creative activities. The first indication applies to the fact that the development of digital technologies introduces a new digital order of communication (from the primary order, through the secondary and hybrid order, to the digital order), which in turn provides communicators with a broad spectrum of new methods and tools of communication 0 including tools permitting creative activities. Second of all, it is noted that despite the mentioned rich offer of digital tools and the promotion of creative attitudes, digital media, in particular global social media, are dominated by attitudes of re-production related both to common re-distribution of existing content (sharing, copying and pasting, etc.), and even limiting creativity entirely (likes, tags). The remarks made are compared to opinions of digital media researchers and neurobiologists indicating on the one hand the weakening/ dissolution of the reception of content by digital media (the negative effect of multi-tasking), and on the other hand, the supersaturation of emotions related to the reception of content (negative influence of computer games). In conclusion, attention is turned to the necessity of establishing in contemporary communicators (on all levels of education) of digital communication competences, in particular the promotion of creative attitudes related to these competences.

KEY WORDS: education, multimedia, culture, digital technologies, digital humanities, creativity 
Specyfika złożoności komunikacyjnej początku XXI w., wpływająca w sposób bezpośredni na postawy kreatywne cyfrowych komunikatorów ${ }^{1}$, związana jest ze współistnieniem w życiu codziennym dwóch podstawowych dzisiaj systemów komunikacyjnych: analogowego, związanego z praktykami i narzędziami komunikacyjnymi wynikającymi z pierwotnego werbalnego i niewerbalnego porządku wzrokowo-słuchowego realizowanego interpersonalnie i pośrednio z wykorzystaniem mediów analogowych i cyfrowego, związanego wyłącznie z praktykami i narzędziami wywodzącymi się z świata technologii informatycznych (cyfrowych). Oba porządki odmiennie regulują i organizują sposoby i formy komunikowania się zaś różnice są tak zasadnicze, że jedyną de facto dominującą dzisiaj (choć przejściową według wspomnianego wcześniej Kurzweila) formułą komunikowania się ludzi ${ }^{2}$ jest komunikacja hybrydowa polegająca na nieustannym przechodzeniu/przełączaniu się komunikatorów pomiędzy obydwoma systemami (przykładem tej „schizofrenii komunikacyjnej" jest jednoczesne wspólistnienie osób, zwłaszcza tak zwanych osób publicznych, jako bytu fizycznego i medialnego bytu wirtualnego) $)^{3}$.

${ }^{1}$ Określenia komunikator cyfrowy używam dla opisu osoby uczestniczącej $\mathrm{w}$ procesie komunikacji za pośrednictwem nowych mediów cyfrowych zarówno $\mathrm{w}$ formie nadawcy (komunikator aktywny) jak i odbiorcy (komunikator pasywny) komunikującej się zarówno z innymi osobami jak i maszynami. Aktywny komunikator cyfrowy to także osoba, która świadomie tworzy/przetwarza/udostępnia treści cyfrowe zaś pasywny komunikator cyfrowy to osoba wyłącznie odbierającą treści udostępnione przez innych użytkowników sieci. W specyficznych przypadkach możemy mówić np. o responsywnym i nieresponsywnym cyfrowym komunikatorze pasywnym - nieresponsywnym odbiorcą jest na przykład bierny widz odtwarzanego poprzez internet filmu zaś responsywnym odbiorcą będzie osoba, która aktywnie uczestniczy w takiej projekcji (np. korzysta z funkcji narzędzia, przewija, pauzuje, komentuje i ocenia poprzez wbudowane narzędzia itp.).

2 Choć przyznać należy, że od początku istnienia maszyny próbują komunikować się z ludźmi w systemie analogowym a w rzeczywistości XXI w. komunikacja ta ma formułę coraz bardziej autonomiczną. 


\section{Język nowym mediów, czyli w kreatywność w granicach kodu}

O ile dość łatwo jest zrozumieć ekonomiczne źródła dynamicznej ekspansji technologii informatycznych i nowych mediów cyfrowych, to nieco trudniejsze wydaje się wyjaśnienie społecznej popularności mediów cyfrowych skutkującej ich powszechnością i wszechobecnością w życiu społecznym i kulturalnym XXI w. Dość powiedzieć, że w ciągu nie więcej niż 20 lat (od połowy lat 90. XX w. do około roku 2015) technologie cyfrowe całkowicie przemodelowały współczesną kulturę popularną, czyniąc z przekazów niszowych, typowych np. dla komiksu lub gier komputerowych, przekaz mainstreamowy w skali globalnej, wpływający na zbiorową świadomość kulturową. Jedne z najprostszych źródeł takiego stanu rzeczy kryją się we wspomnianej ekonomii (zmiana cyfrowa się po prostu opła$\left.\mathrm{ca}^{4}\right)$, ale także w naturze człowieka - jeśli coś jest tanie i proste (również w odbiorze) to szybko staje się popularne i powszechne stając się dobrem wspólnym. Działają tu dwa podstawowe prawa: pierwsze jest dziełem Kopernika-Greshama i mówi, że gorszy (tańszy w produkcji) pieniądz wypiera lepszy5. Drugie generalne prawo streścił w filmie „Rejs” Marek Piwowski ustami inżyniera Mamonia,

${ }^{3}$ Zob. M. Wobalis, Hybrydowy podręcznik multimedialny narzędziem czytania tekstów kultury, [w:] Teksty kultury w szkole, red. B. Myrdzik, L. Tymiakin, Wydawnictwo Uniwersytetu Marii Curie-Skłodowskiej, Lublin 2008, s. 377-386; L.W. Zacher, Refleksje o ideologii cyfrowego świata, [w:] L.W. Zacher, Nasza cyfrowa przyszłość. Nadzieje - ryzyka - znaki zapytania, Komitet Prognoz „Polska 2000 Plus” przy Prezydium PAN, Warszawa 2012, s. 115; S. Puppel, The human communication orders and the principle of natural language sustainability, "Oikeios Logos” 2012, nr 9, s. 9-10. http:/ / www.keko.amu.edu.pl/sites/default/files/oikeios_logos_nr9.pdf [17.08.2018].

4 Jednym z tysięcy przykładów redukcji kosztów dzięki rewolucji cyfrowej może być proces modernizacji technologii odtwarzania filmów w kinach z kosztownych (i niebezpiecznych) odtwarzaczy celuloidowych taśm szpulowych na radykalnie tańsze i bezpieczniejsze nośniki cyfrowe.

5 Prawo to uwzględnia nawet magazynowanie „wyższej” kultury. https://pl. wikipedia.org/wiki/Prawo_Kopernika-Greshama [dostęp: 3.09.2018]. 
które głosi, że najbardziej podobają się te piosenki (czyli teksty kultury), które już wcześniej się poznało ${ }^{6}$. Oba te prawa mają kluczowe znaczenie dla zrozumienia XXI-wiecznej skonwertowanej kultury, którą na potrzeby niniejsze pracy określę mianem kultury imitacji ${ }^{7}$. To, co dawniej wydawało się niszowe i lokalne, w dzisiejszych czasach staje się powszechne i globalne, to, co podobało się wąskiej grupie odbiorców, dzięki internetowi staje się masowe (często ignorując kryteria estetyczne, etyczne czy prawne). Jak wykażemy za chwilę, kluczowe znaczenie dla natychmiastowego i globalnego rozpowszechnienia się kultury cyfrowej ma przede wszystkim sama specyfika budowy języka nowych mediów i ścisłe powiązanie przekazu cyfrowego z nośnikiem technologicznym.

Podstawowym budulcem każdego przekazu cyfrowego jest bit jako najmniejszy znacznik informacji, który nie dość, że nie ma formy fizycznej to $\mathrm{w}$ dodatku jedynie określa stan napięcia elektrycznego $\mathrm{w}$ zamkniętym układzie elektronicznym. Od lat 50. XX w. za Claudem Shannonem możemy więc określić zarówno sposób wirtualnego "łączenia" pojedynczych bitów w większe porcje informacji, przekazywania ich poprzez różnorodne łącza, a w końcu przetwarzania ich w struktury uproszczone algorytmicznie (skompresowane) zgodnie z zasadami entropii informacyjnej. Niezależnie jednak od całego sztafażu technologicznego komunikacji cyfrowej, tym, co konstytuuje istnienie cyfrowego bytu, jest wyłącznie ten wymieniony wyżej stan napięcia elektrycznego: albo owo napięcie jest (1), albo go nie ma (0). Tym samym każda bardziej złożona forma informacji w formie obrazu, dźwięku, tekstu, filmu, gry kompu-

${ }^{6}$ „Proszę pana, ja jestem umysł ścisły. Mnie się podobają melodie, które już raz słyszałem. Po prostu. No... To... Poprzez... No reminiscencję. No jakże może podobać mi się piosenka, którą pierwszy raz słyszę". https://pl.wikiquote.org/ wiki/Rejs [dostęp: 3.09.2018].

${ }^{7}$ Imitacja: 1. „przedmiot nieoryginalny, powtarzający cechy wzorca, wykonany na ogół z materiału tańszego lub gorszej jakości; duplikat, falsyfikat, kopia, podróbka"; 2. odtwórcze działanie mające na celu dokładne powtórzenie cech wzorca; imitowanie, imitatorstwo, naśladownictwo. Online: https://sjp.pl/imitacja [dostęp: 3.09.2018]. 
terowej zawiera w sobie ten sam składnik - 0 lub $1 \mathrm{w}$ formie zwielokrotnionej przez odpowiedni dla danej formy kod. Bit postrzegany metaforycznie jest więc dla świata cyfrowego tym, czym dla świata fizycznego jest najprostsza cząsteczka - różnica polega jednak na tym, że pierwsze jest wyłącznie wirtualnym stanem zaś drugie zawsze materialnym konstruktem złożonym z dwóch lub więcej atomów. Uwaga powyższa, dotycząca fizyczności bytu materialnego, wydaje się konieczna dla zrozumienia najistotniejszych ograniczeń cyfrowego środowiska, w którym realizowane są współczesne cyfrowe praktyki komunikacyjne (w tym twórcze). Środowisko to jest bowiem zawsze: a) wirtualne - „istnieje” w przestrzeni urządzenia elektronicznego i tylko poprzez urządzenie tego typu jest dostępne, b) technologiczne - „istnieje” wyłącznie poprzez urządzenia korzystające $z$ infrastruktury opartej na technologii elektrycznej, c) umowne - reprezentacja zmysłowa bytu wirtualnego postrzegalna przez człowieka jest zawsze zależna od narzędzia transmitującego, a więc dla różnych odbiorców może mieć różną formę, d) zamknięte - przekaz zawsze ograniczony jest możliwościami urządzeń oraz założeniami zapisanego kodem algorytmu. Idąc dalej, każda komunikacyjna forma działania w takim ograniczonym środowisku posiadać będzie te dwie zasadnicze wady wrodzone: jedna wynikać z konieczności pełnego zanurzenia się w jednym tylko środowisku (nie da się połączyć bitu i cząsteczki i nie da się jednocześnie być analogowym i cyfrowym), druga zaś wynikać będzie z konieczności stosowania całkowicie odmiennych narzędzi poruszania się $\mathrm{w}$ danej przestrzeni (nie da się przenieść rzeczywistości cyfrowej do świata materialnego bez użycia technologii zależnych od prądu elektrycznego).

Wymieniono generalne ograniczenia przestrzeni komunikacyjnej odbiorcy/twórcy w ramach rzeczywistości cyfrowej. Kolejne wynikają z samej konstrukcji przekazu cyfrowego o czym obszernie pisał m.in. Lev Manovich. Autor Języka nowych mediów 8 wyodrębnił

${ }^{8}$ L. Manovich, Jezzyk nowych mediów, Oficyna Wydawnicza Łośgraf, Warszawa 2012. 
pięć zasad, które charakteryzują/opisują nowe cyfrowe media: reprezentację numeryczną, modularność, wariacyjność, automatyzacje oraz transkodowanie kulturowe. Każda z cech nowych mediów jeśli przyjrzymy im się pod kątem wpływu na postawy kreatywne, odgrywa istotne znaczenie dla powstawania i form realizowania cyfrowych praktyk twórczych.

Opisywane przez Manovicha zasady konstytutywne języka nowych mediów mają swoje źródło w ich reprezentacji numerycznej, a więc opisywanej już wyżej cyfrowości przekazu. Przekaz numeryczny, niezależnie od tego, czy powstał bezpośrednio w narzędziu cyfrowym, czy został do tego narzędzia przeniesiony poprzez digitalizację, zawsze opisywać będzie świat językiem bitów i niczym więcej. Biorąc pod uwagę, że każdy obiekt nowych mediów (tekst, obraz, dźwięki, wideo) można zapisać matematycznie w kodzie maszynowym, można go w niezwykle prosty sposób poddać obróbce algorytmicznej przez dowolnej klasy cyfrowe urządzenie obliczeniowe. Najczęściej spotykanymi zabiegami tego typu są np. automatyczna poprawa kontrastu lub nasycenia kolorów fotografii, zmiana głośności dźwięku, tempa odtwarzania filmu, wielkości czcionki ${ }^{9}$.

Ważną z cech nowych mediów, wynikającą bezpośrednio z numeryczności, jest ich modularność, oznaczająca zjawisko konstruowania przekazu z niezależnych od siebie części, na które składają się kolejne grupy innych niezależnych części, aż do poziomu niepodzielnych elementów przekazu cyfrowego (takich jak np. piksele w obrazie). Taka konstrukcja przekazu sprawia, że w bardzo łatwo

${ }^{9}$ Por. N. Negroponte, Cyfrowe życie. Jak się odnaleźć w świecie komputerów, Książka i Wiedza, Warszawa 1997. Współcześnie jesteśmy w stanie przechowywać (magazynować) zdigitalizowane kopie analogowych informacji zapisanych na różnych nośnikach od kilku do nawet kilkuset lat bez żadnej straty; zob. T. Bliski, Pamięć nośniki i systemy przechowywania danych, WNT, Warszawa 2008; D. Witczak, K. Sobkowiak, Problemy przechowywania danych cyfrowych w bibliotekach, "Elektroniczne czasopismo Biblioteki Głównej Uniwersytetu Pedagogicznego w Krakowie" 2014, nr 5, http://www.bg.up.krakow.pl/newbie/index.php/bie/article/viewFile/70/69 [dostęp: 20.06.2017]. 
można dokonać ingerencji (przetworzenia, usunięcia, zamiany) w ramach poszczególnych elementów przekazu, nie wpływając na strukturę całości. Modularność spotykamy najczęściej edytorstwie fotografii cyfrowej (usuwanie błędów, korygowanie wyglądu), reklamie, sztuce cyfrowej. W związku z tym, że istnieją dziesiątki aplikacji umożliwiających tego rodzaju edycję, jest to także bardzo popularna metoda szybkiego wyrażania opinii w formie obrazkowej (tzw. memy). W muzyce modularność odpowiada za umożliwienie twórcom swobodnego miksowania (mieszania) i remiksowania (ponownego mieszania) ścieżek dźwiękowych. W studiach nagraniowych oraz profesjonalnych laboratoriach filmowych dzięki modularności możliwe staje się cyfrowe naprawianie, czyszczenie (tzw. remasterowanie) zniszczonych lub uszkodzonych analogowych nagrań lub filmów ${ }^{10}$.

Kolejną ważną z punktu widzenia medialnej kreatywności cechą nowych mediów jest ich wariacyjność. Oznacza ona wielość możliwych do utworzenia wersji cyfrowego obiektu, niezależnie od jego formatu, wielkości czy zawartości. Jak wskazuje Manovich, żaden cyfrowy obiekt nie jest czymś ustalonym raz na zawsze - zawsze może bowiem istnieć w wielu odmiennych od siebie wersjach czyli wariacjach. Multiplikacja wersji jest operacją z założenia niezwykle prostą dla urządzeń informatycznych (bo jest maszynowa) i polega na powielaniu elementów kodu. W tym kontekście liczba kopii, wersji, wariantów może być teoretycznie nieskończona ${ }^{11}$.

Z opisanymi wyżej cechami nowych mediów cyfrowych doskonale wiąże się możliwość maszynowej automatyzacji, która sprawia, że każde działanie odnoszące się do ingerencji w kod (stworzenie kodu, przetworzenie kodu, dystrybucja kodu) może zostać wspomożone pełną automatyzacją (tzw. niskopoziomową zarządzaną przez funkcję aplikacji) ograniczoną wyłącznie możliwościami technicznymi urządzenia. Dzięki automatyzacji i odpowiednio skonstruowanemu algorytmowi program komputerowy, siłami

10 L. Manovich, op. cit., s. 95-97.

11 Ibidem, s. 102-114. 
technologii informatycznej, może samodzielnie wykonać za człowieka liczne czynności według założonego wcześniej schematu, m.in. wyostrzanie obrazu, usuwanie "szumów" w ścieżce dźwiękowej, nakładanie filtrów, efektów itp. Tak też działać może maszyna/program komputerowy, które za człowieka może tworzyć formy artystyczne - maszyna taka sama może zbierać dane (np. w ulubionej kolorystyce lub tematyce) i przetwarzać obrazy/dźwię$\mathrm{ki} /$ teksty, tworząc całkowicie nowe wariacje. Taki program istnieje w rzeczywistości i nazywa się (dość symbolicznie) „Painting Fool”. Stworzony został przez Simona Coltona w roku 2006, a jego „działalność artystyczna" polega na pozyskiwaniu wzorów/pomysłów/inspiracji z sieci Internet i tworzenia ich imitacji (z pomocą odpowiedniego algorytmu). Najczęściej jednak „Painting Fool” w sposób losowy tworzy kolaże, abstrakcje czy różne wizualne kreacje imitujące prawdziwą sztukę ${ }^{12}$. Stworzono również kilka robotów graficznych, nazywanych przez ich twórców "artystami”, których proces twórczy polega najczęściej na mechanicznym tworzeniu rysunku/obrazu z dostarczonego wzorca lub obrazu z kamery ${ }^{13}$.

Ostatnią ważną cechą mediów cyfrowych, i najciekawszą z punktu widzenia cyfrowej humanistyki, jest transkodowanie (kulturowe), które Manovich określa mianem głębszej formy automatyzacji i wariacyjności ${ }^{14}$. Autor Języka nowych mediów zauważa, że

12 Aktualnie możliwe jest automatyzowanie wielu złożonych (wielostopniowych a więc wysokopoziomowych) czynności takich jak automatyczne sterowanie samochodami, samolotami (umożliwiające już nie tylko przelot z punktu "a” do punktu „ ale także start i lądowanie), urządzeniami przemysłowymi (samo zarządzające się roboty). Zagadnienia związane z robotyką a szczególnie tworzeniem robotów autonomicznych (np. samochodów poruszających się bez udziału kierowcy) są w ostatnim szeroko komentowane zaś przykłady rozwiązań (np. samochody testowane przez firmę Google) wskazują, że takie produkty i usługi mają szansę stać się codziennością w ciągu kilku najbliższych lat. Por. E. Jezierski, Dynamika robotów, Wydawnictwo Naukowo-Techniczne, Warszawa 2006; W. Ulatowski, Sterowanie ruchem autonomicznie sterowanych pojazdów, „Pomiary Automatyka Robotyka” 2004, nr 1.

13 Robot artysta?? „Blog wiedzy o nowych technologiach”, http://www.blogo tech.eu/index.php/1503-robot-artysta [dostęp: 3.09.2018].

14 L. Manovich, op. cit., s. 114-118. 
skomputeryzowanie podzieliło media na obszar ściśle komputerowy oraz istniejący obok nich (ale i razem $z$ nimi) realny obszar kulturowy. W związku z tym, że te cyfrowe teksty kultury mogą być $\mathrm{z}$ łatwością kopiowane, multiplikowane, przetwarzane, rozpowszechniane i archiwizowane, bardzo szybko stają się także trwałym i żywym kontekstem dla kultury tradycyjnej (analogowej). Obie przestrzenie oddziałują na siebie, w rezultacie czego powstaje nowa kultura cyfrowa będąca mieszanka znaczeń ludzkich i komputerowych.

Działania kreatywne w obrębie nowych mediów cyfrowych są proste, latwe i powszechnie dostępne, a trzymany $\mathrm{w}$ kieszeni nastolatka AD 2018 smartfon to wart setki milionów dolarów superkomputer $\mathrm{z}$ lat $90 . \mathrm{XX}$ w. z możliwością automatyzowania większości podstawowych czynności związanych m.in. z edycją mediów. Zamiana zdjęcia wykonanego aparatem na wersję imitującą rysunek węglem, przekształcenie zdjęcia krajobrazu w obraz impresjonistyczny, spowolnienie zbyt szybkiego utworu muzycznego lub usunięcie wokalizy, oczyszczenie starego zdjęcia lub usunięcie widocznych wad technicznych, montaż kilku krótkich filmów w jeden dłuższy wraz z czołówką i napisami - dla sprawnego użytkownika telefonu komórkowego każde $\mathrm{z}$ tych działań jest bardzo proste i możliwe do wykonania najczęściej "od ręki”. W dodatku tak "stworzone" "dzieło" natychmiast po opracowaniu może zostać opublikowane i wypromowane $\mathrm{z}$ wykorzystaniem kolejnych cyfrowych narzędzi działających w sieci Internet.

Kim więc, w kontekście wymienionych wyżej rozważań jest autor w świecie nowych mediów? Programistą? Modyfikatorem? Odtwórcą? Imitatorem? A może wyłącznie zdolnym operatorem cyfrowych narzędzi?

\section{Przeciążenie informacyjne, czyli mózg uśpiony}

O wpływie przekazu polisensorycznego/multimedialnego na percepcję ich odbiorców napisano setki, jeśli nie tysiące, książek, artykułów, referatów z rozmaitych dziedzin nauki dzięki (od neu- 
robiologii po lingwistykę stosowaną i kulturoznawstwo). Dzięki temu wiemy już dzisiaj dość dobrze, że wpływ przekazu multimedialnego na percepcję jest silny, znaczący i pozostawia trwały ślad w umyśle odbiorcy. Od lat funkcjonuje też, wprowadzone przez Alvina Tofflera jeszcze w latach 70. XX w., określenie „przeciążenie informacyjne" (ang. information overload) na nazwanie stanu, gdy zbyt wielka ilość (różnorodność) informacji przekazywanych jednocześnie w sposób istotny zaburza odbiór przekazywanego komunikatu15. Manfred Spitzer poświęcił tzw. uwadze selektywnej (będącej jednym z efektów przeciążenia informacjami) osobny rozdział książki Jak uczy się mózg, notując: „Selektywna uwaga dysponuje określoną i ograniczoną zdolnością przetwarzania informacji (pojemnością), którą kieruje na napływające zadania. Im więcej pojemności skierowane jest na określone zadanie, tym bardziej dzieje się to kosztem innych zadań"16. Informację tę warto zestawić z faktem, że mózg ludzki nie dość, że działa całkowicie autonomicznie (nie możemy np. "siłą woli" nakazać mózgowi, aby skupił się na tylko jednej informacji), to $w$ dodatku jest bardzo ekonomiczny, by nie powiedzieć: oszczędny (a nawet skąpy) w dysponowaniu energią. Jeśli więc pewna czynność umysłowa jest zbyt czasochłonna/pracochłonna/nużąca/męcząca, mózg po prostu przestanie się nią zajmować. O zjawisku tym, a szczególnie skutkach przeciążenia wpływających na powierzchowność odbioru treści cyfrowych (np. podczas oglądania stron internetowych) obszernie pisali Nicholas Carr (Ptytki umyst, Jak Internet wptywa na nasz mózg), Gary Small i Gigi Vorgan (iMózg. Jak przetrwać technologiczna przemianę wspótczesnej umysłowości), a także wspomniany Manfred Spitzer w książce Cyfrowa demencja. W jaki sposób pozbawiamy rozumu siebie i swoje dzieci. Carr zauważa:

Dziesiątki badań prowadzonych przez psychologów, neurobiologów, pedagogów czy projektantów stron internetowych prowadzą do tego

15 A. Toffler, Future Shock, Bantam Books, New York 1970.

${ }^{16}$ M. Spitzer, Jak uczy się mózg, Wydawnictwo Naukowe PWN, Warszawa 2012, s. 113. 
samego wniosku: gdy podłączamy się do sieci, wchodzimy w środowisko, które sprzyja pobieżnemu czytaniu, chaotycznemu myśleniu i powierzchownej nauce. Można oczywiście snuć głębokie refleksje, surfując po Internecie, tak jak można ślizgać się po powierzchni, czytając książkę. Nie jest to jednak typ myślenia, który omawiana technologia wspiera i nagradza ${ }^{17}$.

Jednocześnie cytowani wcześniej neurobiolodzy (szczególnie Spitzer), a zwłaszcza neurodydaktycy (w Polsce warto odwołać się do ustaleń Marzeny Żylińskiej18), słusznie zwracają uwagę na fakt, że współczesne pokolenia cyfrowych komunikatorów są tak wyspecjalizowane w odbiorze cyfrowych mediów, że proces odbioru multiplikowanych komunikatów (tzw. „multitasking”, czyli równoczesne aktywne przeglądanie stron internetowych, słuchanie muzyki i pisanie wiadomości tekstowej) jest dla nich na tyle naturalny, że nie stanowi już dla ich mózgów specjalnej atrakcji - do pobudzenia potrzebują więc albo jeszcze silniejszego bodźca albo istnieć może ryzyko, że ich mózgi zostaną „uśpione”. Umiejętność sprawnego odbierania wielu komunikatów na raz, w tym jednoczesne operowanie częścią z nich, stała się dla grupy badaczy (m.in. Gary Small, Gigi Vorgan) podstawą do twierdzenia (przez część badaczy uważanego za zbyt kontrowersyjnego), że w procesie ewolucji mózgu nastąpiła istotna zmiana powalająca na określenie nowych pokoleń wychowanych w świecie cyfrowych mediów mianem pokolenia cyfrowego, w istotny sposób odróżniającego go od starszych pokoleń analogowych (Prensky opisał ten podział w roku 2001 jako digital natives i digitan imigrants ${ }^{19}$ ). Wśród badaczy mózgu owo „aktywne" klikanie (mówi się nawet o kulturze zappingu) ma gorących

17 N. Carr, Ptytki umyst. Jak Internet wptywa na nasz mózg, Helion, Gliwice 2010, s. $145-146$.

${ }_{18}$ M. Żylińska, Neurodydaktyka, Nauczanie i uczenie się przyjazne mózgowi, Wydawnictwo Naukowe Uniwersytetu Mikołaja Kopernika, Torun 2013.

19 Prensky M., Digital Natives, Digital Immigrants, [w:] On the Horizon, Vol. 9 No. 5, MCB University Press, Bradford 2001, http://www.marcprensky.com/wri ting/Prensky\%20-\%20Digital\%20Natives, \%20Digital\%20Immigrants\%20-\%20Part1.pdf [dostęp: 17.01.2017]. 
przeciwników, gdyż w dłuższej perspektywie prowadzi do osłabienia bodźców oraz powierzchowności odbioru przekazów (oko w szybkim tempie przeskakuje $\mathrm{z}$ jednej informacji na kolejną) ${ }^{20}$. W tym kontekście należy zwrócić uwagę na jeden prosty fakt narzędzia dydaktyczne polegające $\mathrm{w}$ większości na operacjach „klikanych” nie są w pierwszej kolejności narzędziami służącymi do efektywnego przyswajania informacji i uczenia się, ale do nauki sprawnego (może nawet mistrzowskiego) klikania.

Tabela 1. Nieprawidłowy wpływ komputera i internetu na dziecko²1

\begin{tabular}{|l|l|}
\hline \multicolumn{1}{|c|}{ KATEGORIE } & \multicolumn{1}{|c|}{ OBJAWY } \\
\hline Stan zdrowia & $\begin{array}{l}\text { Choroby: oczu, układu kostnego, układu nerwowego, } \\
\text { alergie }\end{array}$ \\
\hline $\begin{array}{l}\text { Porozumiewanie się za po- } \\
\text { mocą internetu }\end{array}$ & $\begin{array}{l}\text { Spłycone, krótkie sygnały, język skrótów, ograniczo- } \\
\text { na gama sygnałów }\end{array}$ \\
\hline Sfera zachowania & $\begin{array}{l}\text { Zachowania: agresywne, aroganckie, wulgarne, pro- } \\
\text { wokujące do kłótni }\end{array}$ \\
\hline Sfera emocjonalna & $\begin{array}{l}\text { Lęki, koszmary senne, uczucia strachu, nadmierna } \\
\text { pobudliwość, znieczulenie na zło, agresję krzywdę }\end{array}$ \\
\hline $\begin{array}{l}\text { Redukcja lub ograniczenie } \\
\text { czasu na: }\end{array}$ & $\begin{array}{l}\text { Bezpó́rednie kontakty społeczne, naukę szkolną, } \\
\text { obowiązki domowe, rodzinne, kontakty, rozmowy } \\
\text { rodzinne, aktywność fizyczną, sport, czytelnictwo, } \\
\text { inne formy uczestnictwa w kulturze wyższej }\end{array}$ \\
\hline Sfera umysłowa & $\begin{array}{l}\text { Relatywizm poznawczy, relatywizm etyczny, bier- } \\
\text { ność i rozleniwienie intelektualne, zatarcie różnicy } \\
\text { pomiędzy rzeczywistością a fikcją, zatarcie różnic } \\
\text { między prawem a bezprawiem, niekorzystne zmiany } \\
\text { w słownictwie }\end{array}$ \\
\hline $\begin{array}{l}\text { Nawiązywanie kontaktów } \\
\text { z niewłaściwymi osobami }\end{array}$ & pedofilami, homoseksualistami, gangami, sektami \\
\hline
\end{tabular}

${ }^{20}$ Zob. A. Zając, Uczenie się w sieci przez zapping, "Neodidagmata” 2011, nr 31/32, s. 109-126.

${ }^{21} \mathrm{~J}$. Izdebska, Multimedia zagrażające wspótczesnemu dziecku, [w:] J. Izdebska, T. Sosnowski, Dziecko i media elektroniczne - nowy wymiar dzieciństwa. Komputer i Internet w życiu dziecka i obraz jego dzieciństwa, Tom 2, Trans Humana Wydawnictwo Uniwersyteckie, Białystok 2005, s. 108. 
$\mathrm{W}$ kontekście poruszanego $\mathrm{w}$ tym miejscu tematu warto zastanowić się nieco dokładniej, jak przekaz cyfrowy oddziałuje przede wszystkim na medialną kreatywność odbiorów (zwłaszcza młodych), a także w jakim stopniu cyfrowy model komunikacji realizowanej przy pomocy narzędzi multimedialnych, szczególnie zaś mediów społecznościowych, takie postawy kreuje bądź stymuluje.

Jedno z ciekawszych analiz oddziaływania nowych mediów na młodego odbiorce prezentuje Jadwiga Izdebska w artykule Multimedia zagrażające wspótczesnemu dziecku, skupiając się głównie na oddziaływaniu mediów na sprawność zmysłów (pomija jednak słuch) a zwłaszcza stan emocjonalny i psychiczny odbiorcy - a te obszary, jak wiadomo, mają szczególnie istotne znaczenie dla chęci/potrzeby wyrażania/realizowania działań kreatywnych:

\section{Twórca/odtwórca w kulturze imitacji}

Przeciążenie informacyjne oraz selektywność i powierzchowność odbioru informacji mają bardzo istotny wpływ na zaburzanie dobrostanu cyfrowych komunikatorów, a tym samym na realizację postaw kreatywnych. Te zaś, będąc o wiele bardziej męczącymi dla przeciążonych multimediami mózgów, są zastępowane znacznie prostszymi i mniej wymagającymi działaniami imitacyjnymi. W tym przypadku istotną „pomoc" dla przeciążonych umysłów, jak wskazał cytowany wcześniej Nicholas Carr, stanowią cyfrowe narzędzia informatyczne, które koncentrują się opcjach związanych z przetwarzaniem i dystrybucją istniejących komunikatów (edit/share/like) niż na żmudnym i czasochłonnym ich tworzeniu od zera. Jak wykazaliśmy w części drugiej, nowe media cyfrowe, już z samej swojej digitalnej natury są przekazami ograniczonymi możliwościami konstytuującego je kodu cyfrowego. Mówiąc najprościej - możemy dzięki narzędziom cyfrowymi wykreować wyłącznie to, co zostało założone na etapie ich tworzenia (np. programowania funkcji urządzenia lub programu komputerowego) i wyłącznie $w$ ramach przestrzeni działań opisanej w kodzie. Jeśli więc urządzenie lub program nie 
ma interesującej twórcę funkcji, musi on szukać kolejnego narzędzia lub (i najczęściej $\mathrm{z}$ braku czasu, braku zaangażowania, talentu, umiejętności informatycznych) ograniczyć się do dostępnych pod ręką funkcji. W ten sposób narzędziem graficznym staje się Facebook, a do montażu filmu, który docelowo obejrzy kilka milionów widzów, wystarczy aplikacja w telefonie. Niezależnie jednak od liczby ogólnie dostępnych funkcji urządzeń i oprogramowania cyfrowy twórca zawsze będzie ograniczony przestrzenią kodu oraz brakiem możliwości wyjścia poza wybrany system komunikacji. Jak wspomnieliśmy wcześniej, język nowych mediów cyfrowych konstytuowany jest przez cechy polegające na kopiowaniu i przekształcaniu istniejącego przekazu przy wykorzystaniu istniejących narzędzi informatycznych niż tworzenie całkowicie nowych treści. Istniejące cyfrowe narzędzia związane z kreacją (np. programy do rysowania, cyfrowe instrumenty muzyczne, cyfrowe aparaty i cyfrowe kamery) obudowane są tak wieloma funkcjami automatycznymi, że już na etapie kreowania nowego dzieła de facto tworzone ono jest albo z szablonu albo poprzez szablon umożliwiający modyfikację istniejącego dzieła. Innymi słowy - łatwiej i prościej jest stworzyć „coś nowego" z istniejącego źródła (np. szablonu) niż stworzyć (np. programem malarskim) dzieło oryginalne. Łatwiej i prościej przetworzyć istniejący mem niż stworzyć i wypromować całkowicie nowy, a każda z takich imitacji to opisana przez Manovicha kolejna cyfrowa wariacja oryginału.

Warto zauważyć, że tworzenie imitacji przestało być w we współczesnej kulturze konwergencji postrzegane, jako wada, ułomność lub brak pomysłowości. Dzieje się wręcz przeciwnie - istotną wartością staje się to, co przypomina inne popularne przekazy, a dzięki sprawnej imitacji autor/odtwórca/imitator może pochwalić się dobrą znajomością aktualnego kodu kulturowego. Dla uważnych obserwatorów mediów społecznościowych następujące po sobie cyfrowe mody medialne są łatwe do identyfikacji i sklasyfikowania - również dzięki samym narzędziom informatycznym, które skrzętnie klasyfikują najpopularniejsze przekazy (Top 100 filmów Youtube, najpopularniejsze serwisy Facebook., najchętniej 
obserwowane konta Instagram itp). Zdecydowana większość narzędzi społecznościowych wspiera działania imitacyjne oferując narzędzia w rodzaju like/dislike umożliwiające nie tyle odniesienie się komunikatora do odbieranego przekazu, co przede wszystkim sklasyfikowanie przekazów lubianych bądź nie lubianych. Zamiast komentarza słownego do zdjęcia proponuje się oznaczenie osób kliknięciem myszki, zamiast wyrażenia emocji narzędzie oferuje zestaw gotowych emotikonów obrazujących radość, smutek, złość itd. Coraz wyraźniejsza staje się tendencja operatorów serwisów społecznościowych do odchodzenia od tworzenia samodzielnych komunikatów wymagających złożonych umiejętności pisania (np. tworzenia zdań podrzędnie złożonych) czego dobrym przykładem jest narzucanie komunikatorom np. limitu możliwych do wpisania znaków (liter).

Innym wartym zauważenia narzędziem wspierającym działania imitacyjne jest opcja share/re-share umożliwiająca redystrybucję najbardziej popularnych przekazów zamiast bardziej złożonego skomentowania/polecenia ulubionego przekazu. Udostępnienie przekazu traktuje się jak jego polecenie pozostałym komunikatorom, a tym samym włączenie się osoby udostępniającej do sieci oficjalnych i nieoficjalnych dystrybutorów cyfrowych przekazów. Tym samym $w$ kulturze imitacji obserwujemy powtarzające się zjawiska pojawiania się krótkotrwałych gwiazd medialnych osiągających w krótkim czasie wielomilionowe wskaźniki nie tylko widzów, ale również redystrybutorów, a następnej kolejności imitatorów. W tak postrzeganej cyfrowej kulturze imitacji istotną rolę odgrywają nowość (inaczej świeżość przekazu) i jego popularność częstokroć osiągane najprostszymi/najprymitywniejszymi środkami np. poprzez kontrowersyjność lub świadome odwołanie się do innego popularnego przekazu. Mniejszą rolę zwraca się już nie tylko na jakość estetyczną, innowacyjność czy wymogi prawne, ale nawet na jakość techniczną przekazu.

Od czasu dynamicznego rozpowszechnienia się mediów cyfrowych (w późnych latach 90. XX w. m.in. Napster, później serwisy korzystające z protokołu BitTorrent), a później mediów społeczno- 
ściowych i serwisów strumieniowego przesyłania plików (MySpace, YouTube, Spotify, Napster itp.) zauważalne jest kontestowanie, a nawet kwestionowanie zasadności restrykcyjnego dbania o prawa autorskiego do materiałów udostępnianych w globalnej sieci. Część najbardziej radykalnych użytkowników sieci uznaje prawo każdego jej użytkownika do swobodnego korzystania z dowolnych treści $\mathrm{w}$ dowolny sposób. W odbiorze powszechnym i w realiach kultury imitacji podejście takie skutkuje nie tylko działaniami polegającymi na "przywłaszczaniu” szczególnie popularnych nazw, imion czy nawet wizerunków znajdowanych $\mathrm{w}$ globalnej sieci. Tym sposobem żyjący w świecie realnym twórca świadomie i z własnej woli zamienia się w byt wirtualny opisywany cyfrowym nickiem i awatarem.

\section{W poszukiwaniu kreatywności}

W sytuacji tak powszechnej dostępności narzędzi cyfrowych i w warunkach tak silnie zglobalizowanej cyfrowej kultury medialnej (będącej w dodatku jak staraliśmy się to wykazać kulturą opartą na imitacji) niezwykle trudno jest prognozować jakąkolwiek wizję przyszłości w odniesieniu do postaw kreatywnych. Mimo to, można pokusić się o sformułowanie kilku konkluzji mających charakter nieco ogólny i wykraczający poza ograniczenia technologiczne, które zawsze są zmienne.

Przede wszystkim współczesna rzeczywistość technologiczna jest stanem przejściowym $\mathrm{w}$ kierunek dalszego rozwoju narzędzi cyfrowych jest trudny do przewidzenia. Aktualnie stosowane interfejsy używane do komunikowania się człowieka z maszyną są całkowicie przestarzałe. Klawiatura ma ponad 100 lat, mysz komputerowa jest tylko o 50 lat młodsza, monitory komputerowe - a raczej styl życia, które wymuszają, odpowiadają za coraz większą grupę schorzeń cywilizacyjnych. Jakie będą interfejsy przyszłości? Z pewnością inne niż dzisiaj, a tendencja ich rozwoju oraz ostatnie trendy wskazują, że zarządzanie urządzeniami stawać się będzie coraz bardziej zbliżone do naturalnych form komunikacji człowieka, 
obejmując m.in. możliwość bezpośredniego komunikowania się człowieka z maszyną poprzez zmysły.

Niezależnie jednak od tego, w jakim kierunku zmierzać będzie dalszy rozwój technologii kompetencjami, które wyróżniać będą człowieka w opozycji do maszyn przyszłości, będą umiejętność kreatywnego/krytycznego myślenia i złożone, wielopoziomowe kompetencje komunikacyjne obejmujące już nie tylko dotychczasowe sposoby komunikacji (mowę, pismo, komunikację niewerbalną itd.), ale także empatię, intuicję oraz skłonność do podejmowania ryzyka. W zdecydowanym odwrocie będą za to wszystkie te kompetencje, które będą mogły być symulowane przez maszyny i zarządzającą nimi sztuczną inteligencję. W takim ujęciu główny nacisk edukacji w kolejnych latach na wszystkich poziomach edukacji należy położyć na rozwój kompetencji komunikacyjnych związanych zarówno z lepszym komunikowaniem się między ludźmi w świecie fizycznym, ale także cyfrowych kompetencji komunikacyjnych usprawniających komunikowanie się człowieka z bytami wirtualnymi. Niezależnie jednak od powyższego - najistotniejsze stanie się rozwijanie kompetencji umożliwiających człowiekowi osiągnięcie harmonii egzystencjalnej $\mathrm{w}$ tym realizowanie postaw twórczych i osiąganie życiowego dobrostanu.

\section{Bibliografia}

Bliski T., Pamięć nośniki i systemy przechowywania danych, WNT, Warszawa 2008.

Carr N., Płytki umyst. Jak Internet wptywa na nasz mózg, Helion, Gliwice 2010.

Izdebska J., Multimedia zagrażajace wspótczesnemu dziecku, [w:] J. Izdebska, T. Sosnowski, Dziecko i media elektroniczne - nowy wymiar dzieciństwa. Komputer i Internet w życiu dziecka i obraz jego dzieciństwa. Tom 2, Trans Humana Wydawnictwo Uniwersyteckie, Białystok 2005.

Manovich L., Język nowych mediów, Oficyna Wydawnicza Łośgraf, Warszawa 2012.

Negroponte N., Cyfrowe życie. Jak się odnaleźć w świecie komputerów, Książka i Wiedza, Warszawa 1997. http://www.keko.amu.edu.pl/sites/default/files/oikeios_lo gos_nr9.pdf [dostęp: 17.08.2018].

Prensky M., Digital Natives, Digital Immigrants [w:] On the Horizon, Vol. 9 No. 5, MCB University Press, Bradford 2001, http:/ / www.marcprensky.com/writing/ 
Prensky\%20-\%20Digital\%20Natives, \%20Digital\%20Immigrants\%20-\%20Part1.pdf [dostęp: 17.01.2017].

Puppel S., The human communication orders and the principle of natural language sustainability, „Oikeios Logos” 2012, nr 9, s. 9-10.

Spitzer M., Jak uczy się mózg, Wydawnictwo Naukowe PWN, Warszawa 2012

Toffler A., Future Shock, Bantam Books, New York 1970.

Witczak D., Sobkowiak K., Problemy przechowywania danych cyfrowych w bibliotekach, „Elektroniczne czasopismo Biblioteki Głównej Uniwersytetu Pedagogicznego w Krakowie", 2014 nr 5. http://www.bg.up.krakow.pl/newbie/index.php/ bie/article/viewFile/70/69 [dostęp: 20.06.2017].

Wobalis M., Hybrydowy podręcznik multimedialny narzędziem czytania tekstów kultury, [w:] Teksty kultury w szkole, red. B. Myrdzik, L. Tymiakin, Wydawnictwo Uniwersytetu Marii Curie-Skłodowskiej, Lublin 2008.

Zacher L. W., Refleksje o ideologii cyfrowego świata, [w:] L.W. Zacher, Nasza cyfrowa przyszłość. Nadzieje - ryzyka - znaki zapytania, Komitet Prognoz „Polska 2000 Plus” przy Prezydium PAN, Warszawa 2012.

Zając A., Uczenie się w sieci przez zapping, „Neodidagmata” 2011, nr 31/32, s. 109-126

Żylińska M., Neurodydaktyka, Nauczanie i uczenie się przyjazne mózgowi, Wydawnictwo Naukowe Uniwersytetu Mikołaja Kopernika, Toruń 2013.

\section{Źródła internetowe}

https://pl.wikiquote.org/wiki/Rejs, [dostęp: 3.09.2018].

https://pl.wikipedia.org/wiki/Prawo_Kopernika-Greshama [dostęp: 3.09.2018]. 